\title{
The cytokine profile of human NKT cells and PBMCs is dependent on donor sex and stimulus
}

\author{
Hannah Bernin ${ }^{1} \cdot$ Helena Fehling ${ }^{1} \cdot$ Claudia Marggraff $^{1} \cdot$ Egbert Tannich $^{1} \cdot$ \\ Hannelore Lotter ${ }^{1}$
}

Received: 14 January 2016 / Accepted: 24 January 2016 / Published online: 20 February 2016

(C) The Author(s) 2016. This article is published with open access at Springerlink.com

\begin{abstract}
Sex-related variations in natural killer T (NKT) cells may influence immunoregulation and outcome of infectious and autoimmune diseases. We analyzed sex-specific differences in peripheral blood NKTs and peripheral blood mononuclear cells (PBMCs) from men and women and determined the frequencies of NKT cells and their subpopulations $\left[\mathrm{CD}^{+}\right.$; $\mathrm{CD} 8^{+}$; double negative (DN)] and the levels of cytokine production following stimulation with the NKT cell ligands $\alpha$-Galactosylceramide ( $\alpha$ GalCer) and Entamoeba histolytica lipopeptidephosphoglycan (Lotter et al. in PLoS Pathog 5(5):e1000434, 2009). Total and DN NKT cells were more abundant in women than in men. In women, $\alpha$ GalCer induced higher production of intracellular IFN $\gamma$, IL-4, IL-17 and TNF by CD4 ${ }^{+}$and $\mathrm{DN}^{+} \mathrm{NKT}$ cells. Both ligands induced expression of multiple cytokines in PBMCs and influenced the ratio of NKT cell subpopulations during long-term culture. Although the sex-specific differences in frequencies of NKT cells and their subpopulations were marginal, the significant sex-specific
\end{abstract}

Hannelore Lotter lotter@bnitm.de

Hannah Bernin

bernin@bnitm.de

Helena Fehling

fehling@bnitm.de

Claudia Marggraff

marggraff@bnitm.de

Egbert Tannich

tannich@bnitm.de

1 Department of Molecular Parasitology, Bernhard Nocht Institute for Tropical Medicine, Bernhard-Nocht-Str. 74, 20359 Hamburg, Germany differences in cytokine production might influence disease outcomes.

Keywords Sex difference - Immune response - NKT cells $\cdot$ Human $\cdot \alpha \mathrm{GalCer} \cdot$ Entamoeba histolytica .

Cytokines $\cdot$ Glycolipid
Abbreviations
$\alpha$ GalCer $\quad \alpha$ Galactosylceramide
EhLPPG Entamoeba histolytica
DN lipopeptidephosphoglycan
Double negative

\section{Introduction}

Immune responses differ between the sexes. In addition to behavioral, genetic, and hormonal factors, differences in the abundance and activation of various types of immune cells could explain some of the observed sexual dimorphisms in infectious diseases [2, 3]. Sex-specific differences in immune responses of women and men could underlie the higher susceptibility of men to infectious diseases caused by bacteria, viruses and parasites, e.g., tuberculosis [4], influenza A [5] and amebiasis [6-8]. By contrast, women exhibit more vigorous humoral and cellular immune responses and are more susceptible to cell-mediated autoimmune diseases $[9,10]$.

The relative proportions of certain immune cell populations differ between men and women. Men have higher monocyte counts [2] but a lower percentage of $\mathrm{T}$ lymphocytes within the total lymphocyte population [10]. A rare T cell subset, the invariant natural killer T (NKT) cells, also exhibits sex-related differences in frequency and is more abundant in women than in men [11-13]. NKT cells have 
immunomodulatory properties, bridge the innate and adaptive immune response and play crucial roles in a variety of infectious diseases, autoimmune disorders and cancers [14-16]. They express an invariant $\mathrm{T}$ cell receptor (TCR) that consists of the V $\alpha 24-J \alpha 18 / \mathrm{V} \beta 11$ chains in humans and $\mathrm{V} \alpha 14-\mathrm{J} \alpha 18 / \mathrm{V} \beta 8.2$ chains in mice. Based on their expression of CD4 and CD8, NKT cells can be divided into three subpopulations: $\mathrm{CD}^{+}, \mathrm{CD}^{+}$and $\mathrm{CD}^{-} \mathrm{CD}^{-}$(double negative; $\mathrm{DN})$ [14]. Whereas conventional $\mathrm{T}$ cells recognize protein antigens in the context of MHC class I and II molecules, NKT cells recognize exclusively glycolipid and lipid antigens presented by the MHC I-like molecule CD1d [17]. Activated NKT cells can produce different pro- and antiinflammatory cytokines, including interferon (IFN) $\gamma$, tumor necrosis factor $\alpha$ (TNF), interleukin (IL)-2, IL-4, IL-17, and tumor growth factor (TGF) $\beta$ [18-20]. The strongest NKT cell activator identified to date is $\alpha$-Galactosylceramide $(\alpha \mathrm{GalCer})$, a lipid molecule originally isolated from a marine sponge [21, 22]. Although NKT cells are attractive targets for immunotherapies, the very strong activation by $\alpha \mathrm{GalCer}$ limits the clinical utility of this compound. Therefore, more moderate ligands provided by other microorganisms should be considered [23].

We recently isolated a glycolipid molecule from the membrane of a protozoan parasite, the Entamoeba histolytica lipopeptidephosphoglycan (EhLPPG). EhLPPG induces substantial IFN $\gamma$ production in murine NKT cells in a CD1d-dependent manner, and treatment of mice with EhLPPG considerably reduces abscesses in a murine model of hepatic amebiasis [1].

NKT cells are modulated by sex hormones such as $17 \beta$-estradiol and testosterone, leading to sex-specific differences in NKT-mediated immune responses. For example, treatment of mice with $\alpha \mathrm{GalCer}$ increases the serum IFN $\gamma$ levels in females, but not in males. This difference is absent in estrogen receptor-deficient mice or ovariectomized mice [24]. By contrast, testosterone substitution lowers the female resistance to hepatic amebiasis by decreasing IFN $\gamma$ production in NKT cells [25].

In this study, we measured the frequencies of NKT cell and their subpopulations in men and women and analyzed the cytokines by stimulation with $\alpha \mathrm{GalCer}$ and EhLPPG. We also analyze the cytokine induction also in bystander cells and investigated the influence of $\alpha \mathrm{GalCer}$ and EhLPPG on NKT cell subpopulations upon enrichment.

\section{Materials and methods}

\section{Human subjects and isolation of PBMCs}

Peripheral blood mononuclear cells (PBMCs) from buffy coats or fresh blood samples from blood donors [23 men $(31-53 ; 43.7$ years \pm 5.8$]$ and 22 women [33-51; 42.7 years \pm 6.1$)]$ were used for cytokine analysis of NKT cells following stimulation with $\alpha \mathrm{GalCer}$ and EhLPPG. The average age of the blood donors ranged between 31 and 54 years $(43.3 \pm 5.8)$. Samples were subjected to flow cytometer, ELISA or used to generate APCs from CD14 ${ }^{+}$ monocytes. Buffy coats for isolation of PBMCs were kindly provided by the Department of Transfusion Medicine of the University Clinic Hamburg-Eppendorf. The cohort size is indicated individually for each experiment. All experiments were approved by the ethical review committee of the medical council of Hamburg (PV3551).

Briefly, PBMCs were isolated by density-gradient centrifugation in Biocoll (Biochrom AG). The leukocyte ring was removed and washed twice with PBS. The resultant pellet was resuspended in $1 \mathrm{ml}$ of X-VIVO ${ }^{\mathrm{TM}} 15$ (LONZA) supplemented with $1 \%$ Pen/Strep (AppliChem Panreac) or in RPMI 1640 (10 \% FCS, 1 \% L-Glutamine, 1 \% Pen/ Strep). PBMCs were then used in human NKT cell or stimulation assays or for generation of APCs.

\section{Intracellular cytokine production in human NKT cells}

The NKT cell cytokine assay was a modification of a protocol described by Sandberg et al. [11]. In brief, $1 \times 10^{6}$ human PBMCs/well were cultured in quadruplicates in 96-well round-bottom plates in X-VIVO ${ }^{\mathrm{TM}} 15$ (LONZA) supplemented with $1 \%$ Pen/Strep (AppliChem Panreac). Cells were stimulated with $1 \mu \mathrm{g} / \mathrm{ml} \alpha \mathrm{GalCer}$ or $10 \mu \mathrm{g} / \mathrm{ml}$ purified EhLPPG. To achieve optimal NKT cell activation without additional APCs, $3 \mu \mathrm{g} / \mathrm{ml}$ purified $\alpha \mathrm{CD} 28$ was added to each well as a co-stimulant. Cells were incubated for $15 \mathrm{~h}$ at $37{ }^{\circ} \mathrm{C}$ in a humidified atmosphere containing $5 \% \mathrm{CO}_{2}$. After $1 \mathrm{~h}, 10 \mu \mathrm{g} / \mathrm{ml}$ brefeldin A was added to the culture to stop Golgi transport. After incubation, cells were harvested and NKT cells were assayed for cytokine production by staining with anti-IFN $\gamma$-PE/Cy7, anti-TNF $\alpha$-FITC, anti-IL-4-PE and anti-IL-17A-BV421 antibodies. NKT cells were stained with anti-CD3-PerCP and anti-TCR $\mathrm{V} \alpha 24-\mathrm{J} \alpha 18-\mathrm{APC}$. All antibodies were obtained from BioLegend. Flow cytometry was performed on a FACS LSRII instrument (BD Biosciences).

Supernatants of an intracellular cytokine assay from a representative donor were tested for 12 analytes (IL2, IL-4, IL-5, IL-6, IL-9, IL-10, IL-17A, IL-17F, IL-21, IL-22, IFN $\gamma$ and TNF $\alpha$ ) using the multi-LEGENDplex ${ }^{\mathrm{TM}}$ analyte flow assay kit (BioLegend). Briefly, antibodies specific for the 12 analytes were conjugated to 12 different fluorescence-encoded beads. The beads were mixed with serum samples (diluted twofold), incubated with shaking for $2 \mathrm{~h}$ at room temperature, washed, and incubated for $1 \mathrm{~h}$ with a cocktail of 12 different biotinylated detection antibodies. Finally, streptavidin-PE was added, the samples 
were incubated for $30 \mathrm{~min}$, and the beads were washed and analyzed.

\section{Generation of APCs from $\mathrm{CD}^{+}{ }^{+}$monocytes}

To generate APCs, PBMCs were labeled with BD IMagTM Anti-Human CD14 Magnetic Particles (BD Biosciences). Next, $1 \times 10^{6} \mathrm{CD} 14^{+}$monocytes were plated in 6-well plates in $5 \mathrm{ml}$ of RPMI (10\% FCS, $1 \%$ L-Glutamine, $1 \%$ Pen/Strep) with $500 \mathrm{U} / \mathrm{ml}$ recombinant human IL-4 (Sigma) and $500 \mathrm{U} / \mathrm{ml}$ human GM-CSF (MACS Miltenyi Biotec). On days 3 and 6, half of the media was replaced with fresh media containing IL-4 and GM-CSF. Immature APCs were harvested on day 7 or 8 and used in in vitro NKT cell stimulation assays. APC purity was determined by flow cytometry after staining with anti-CD11c-BV421, anti-HLA-DR-PE and anti-CD14-AF700 antibodies. All antibodies were obtained from BioLegend. The negative PBMC fraction lacking $\mathrm{CD} 14^{+}$monocytes was frozen in liquid nitrogen prior to use.

\section{NKT/PBMC cell activation without or with the addition of separately generated autologous APCs}

For the NKT/PBMC cell assay without APCs, total $5 \times 10^{6}$ PBMCs/well were stimulated with $10 \mu \mathrm{g} / \mathrm{ml} \alpha \mathrm{GalCer}$ or $20 \mu \mathrm{g} / \mathrm{ml}$ EhLPPG in $100 \mu \mathrm{l}$ of RPMI 1640 (10\% FCS, $1 \%$ L-Glutamine, $1 \%$ Pen/Strep) and incubated for $48 \mathrm{~h}$ at $37{ }^{\circ} \mathrm{C}$ under $5 \% \mathrm{CO}_{2}$. For the NKT/PBMC cell assay using the resultant APCs, $1 \times 10^{5} \mathrm{APCs} /$ well were stimulated with $10 \mu \mathrm{g} / \mathrm{ml} \alpha \mathrm{GalCer}$ or $20 \mu \mathrm{g} / \mathrm{ml}$ EhLPPG in $50 \mu \mathrm{l}$ of RPMI 1640 (10\% FCS, $1 \%$ L-Glutamine, $1 \%$ Pen/ Strep) and incubated for $3-4 \mathrm{~h}$ at $37{ }^{\circ} \mathrm{C}$ under $5 \% \mathrm{CO}_{2}$. Next, $5 \times 10^{6}$ thawed PBMCs from the negative (CD14 ${ }^{+}$ monocyte-depleted) PBMC fraction described above was added in $50 \mu \mathrm{l}$ of RPMI 1640 to the stimulated APCs, and the mixed samples were incubated for $48 \mathrm{~h}$ at $37{ }^{\circ} \mathrm{C}$ under $5 \% \mathrm{CO}_{2}$. Both assays were run in duplicate. After $48 \mathrm{~h}$, supernatants were collected and assayed for IFN $\gamma$ using ELISA MAX ${ }^{\mathrm{TM}}$ Standard SET Human IFN $\gamma$ (BioLegend).

\section{Enrichment of human NKT cells}

Enrichment of NKT cells was performed as described previously by Watarai et al. [26]. In brief, $2 \times 10^{6}$ PBMCs were plated in 24-well plates in $1 \mathrm{ml}$ of RPMI (10\% FCS, $1 \%$ L-Glutamine, $1 \%$ Pen/Strep) and specifically stimulated with either $100 \mathrm{ng} / \mathrm{ml} \alpha$ GalCer or $400 \mathrm{ng} / \mathrm{ml} E h \mathrm{LPPG}$ to expand NKT cells at $37{ }^{\circ} \mathrm{C}, 5 \% \mathrm{CO}_{2}$. To encourage proliferation and maturation of $\mathrm{T}$ cells, $20 \mathrm{U} / \mathrm{ml}$ recombinant human IL-2 (rh-IL-2) (Cell Sciences) was added to all wells. rh-IL-2 alone was used as a negative control. Every
3-4 days, half of the media was replaced with fresh media containing $20 \mathrm{U} / \mathrm{ml}$ rh-IL-2. On day $9,5 \times 10^{4}$ APCs stimulated for $24 \mathrm{~h}$ with recombinant human IL-4, GM-CSF and $\alpha$ GalCer or EhLPPG, respectively, were added to the expanding cells. Success of expansion was determined on day 0,8 and 16 via flow cytometry to detect total NKT cells and NKT cell subpopulations.

\section{Statistical analysis}

NKT cell frequencies and cytokine production were compared between women and men by Mann-Whitney $U$ test. Comparisons of the cytokine production in stimulantresponding men and women (responders) and of NKT cell subsets following expansion were performed by unpaired Student's $t$ test. Differences were considered to be significant if $p$ values were as follows: $* p<0.05$; $* *<0.005$; $* * * p<0.0005$.

\section{Results}

\section{Women tend to have higher total and DN NKT cell frequencies than men}

We used flow cytometry to analyze the frequencies of peripheral NKT cells and NKT cell subpopulation in 23 healthy male and 22 healthy female blood donors (Fig. 1ae). The gating strategy is shown in Fig. 1a-c. After gating on lymphocytes, single cells were gated in SSC-A/ SSC-H and only live cells were analyzed. NKT cells positive for NKT TCR (V $\alpha 24-J \alpha 18)$ and CD3 (Fig. 1b) were further divided into their subpopulations $\left(\mathrm{CD}^{+}, \mathrm{CD} 8^{+}\right.$ or DN) (Fig. 1c). Frequencies of peripheral NKT cells varied between 0.01 and $1.18 \%$. The frequency of NKT cells was higher in women $(0.11 \% \pm \mathrm{SD})$ than in men $(0.05 \% \pm \mathrm{SD})$, but this difference was not statistically significant $(p=0.3)$ (Fig. 1d). Analysis of $\mathrm{CD}^{+}, \mathrm{CD}^{+}$ and DN NKT subpopulations did not significantly differ between the sexes (Fig. 1e). The frequencies of $\mathrm{CD}^{+} \mathrm{NKT}$ cells was slightly higher in men (31.4\%) than in women (25.8\%), whereas the frequency of $\mathrm{CD}^{+}$NKT cells did not differ between the sexes (men: $26.1 \%$; women: $23.7 \%)$. DN NKT cells were more abundant in women $(48.9 \%)$ than in men $(40.2 \%)(p=0.1)$.

\section{Comparison of intracellular cytokine production by total NKT cells from men and women}

Following stimulation with $\alpha \mathrm{GalCer}$ and $E h \mathrm{LPPG}$, we analyzed intracellular IFN $\gamma$, TNF, IL-17A and IL-4 production in 25 healthy blood donors (13 men and 12 women) 


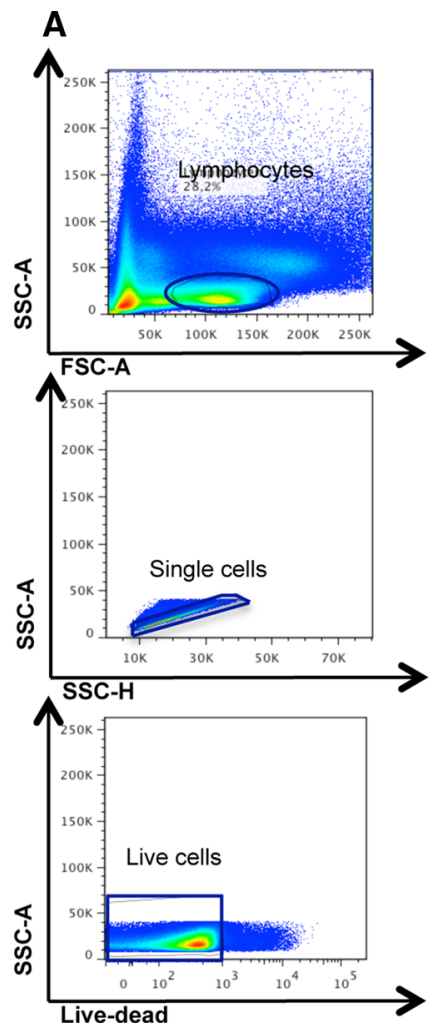

B
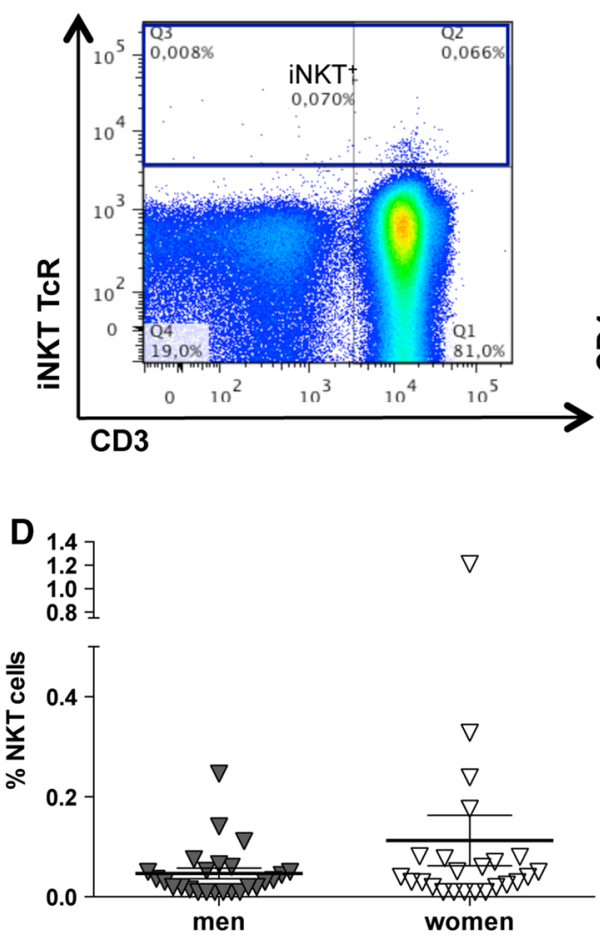

C

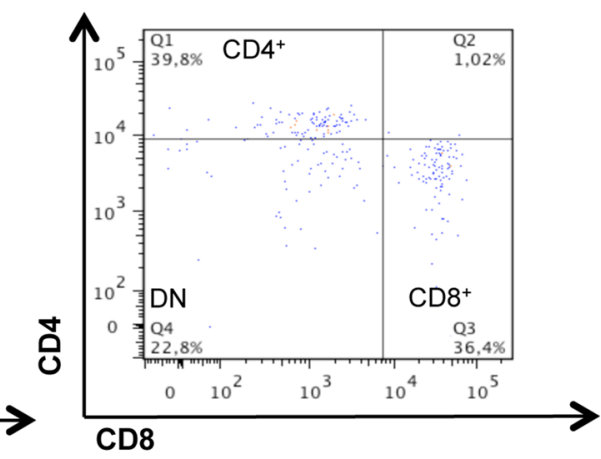

E

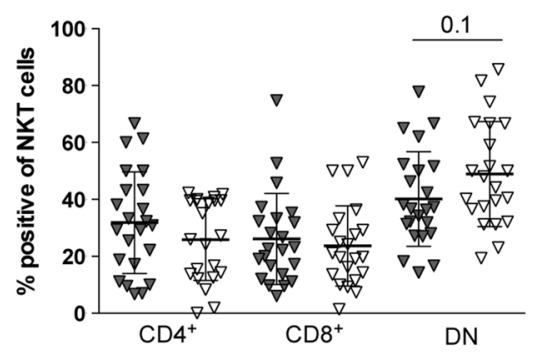

Fig. 1 Frequencies of human peripheral blood NKT cells and NKT cell subpopulations in men and women. a PBMCs from healthy blood donors were analyzed by flow cytometry. Lymphocytes were gated in SSC and FSC, and single live cells were selected. b The frequency of NKT cells was determined by expression of CD3 and
NKT TCR (V $\alpha 24-\mathrm{J} \alpha 18$ TCR). c The frequencies of the NKT cell subpopulations were determined by expression of CD4 and CD8. d Sex-specific frequencies of NKT cells and e NKT cell subpopulations (means \pm SEM; men, $n=23$; women, $n=22$; statistics: MannWhitney $U$ test) by flow cytometry (Fig. 2a-e). The gating strategy is shown in Fig. 2a. Stimulation of NKT cells with the strong NKT cell ligand $\alpha \mathrm{GalCer}$ resulted in a higher percentage of IFN $\gamma^{+} \mathrm{NKT}$ cells in women $(15.6 \%)$ than in men $(7.3 \%)$ (Fig. 2b). Stimulation with EhLPPG resulted in no sexspecific differences in the percentages of IFN $\gamma^{+} \mathrm{NKT}$ cells (men: $12.4 \%$; women: $11.8 \%$ ) The proportion of $\mathrm{TNF} \alpha^{+} \mathrm{NKT}$ cells was significantly higher in women $(0.9 \%)$ than in men $(0.0 \%)$ following $\alpha \mathrm{GalCer}$ stimulation $(p<0.02)$, whereas EhLPPG induced very few TNF $\alpha^{+} \mathrm{NKT}$ cells in either sex (Fig. 2c). Furthermore, $\alpha$ GalCer and $E h$ LPPG both induced higher percentages of IL-17A ${ }^{+} \mathrm{NKT}$ cells in women $(\alpha \mathrm{GalCer}$ : $5.6 \%$; EhLPPG: $1.9 \%)$ than in men ( $\alpha$ GalCer: $0.08 \%$; EhLPPG: $0.07 \%)$ (Fig. 2d); the effect of $\alpha$ GalCer was statistically significant $(p<0.03)$. NKT cells from women also exhibited a higher percentage of IL-4 ${ }^{+}$NKT cells after $\alpha$ GalCer stimulation compared to men $(p<0.056)$ while stimulation with EhLPPG revealed no difference in the percentage of $\mathrm{IL}^{-} 4^{+}$NKT cells between the sexes (women: $15.7 \%$; men: $15.3 \%$ ). Thus, $\alpha$ GalCer stimulation induced a higher percentage of cytokine-producing cells than EhLPPG and significant sexspecific differences in production of TNF, IL-17A and IL-4.

\section{$\mathrm{CD4}^{+}$NKT and DN NKT cells are the major cytokine-producing NKT subpopulations in both sexes}

Next, we sought to determine which NKT cell subpopulations are responsible for the observed cytokine production in men and women (Fig. 3a-e). Figure 3a shows the gating strategy used to determine NKT cell subpopulations. We analyzed cytokine production by $\mathrm{CD}^{+}, \mathrm{CD}^{+}$, and $\mathrm{DN}$ NKT cell subpopulations after stimulation with $\alpha$ GalCer or EhLPPG. Following stimulation with either ligand, $\mathrm{CD} 4{ }^{+}$NKT cells were the primary producers for IFN $\gamma$ production with no significant difference between men and women although the percentage was higher in women after $\alpha$ GalCer stimulation (19.4\%; men: $11.6 \%$ ) (Fig. 3b). $\mathrm{CD}^{+}$and DN NKT cells contributed only weakly to IFN $\gamma$ production. $\mathrm{TNF}^{+} \mathrm{NKT}$ cells were very scarce and were detectable only following $\alpha$ GalCer stimulation in DN NKT cells from women (Fig. 3c). 


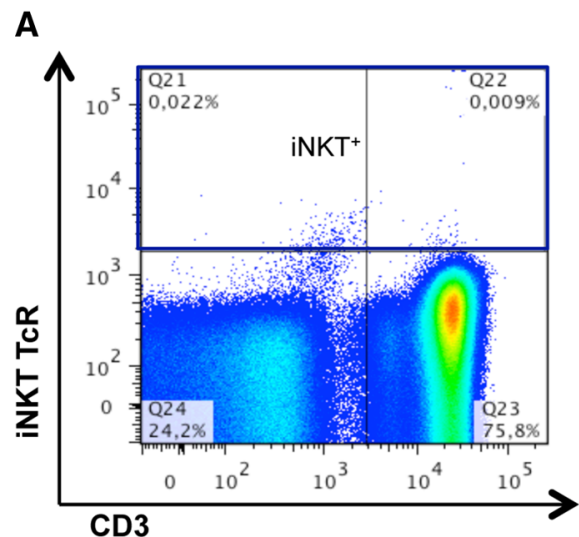

B
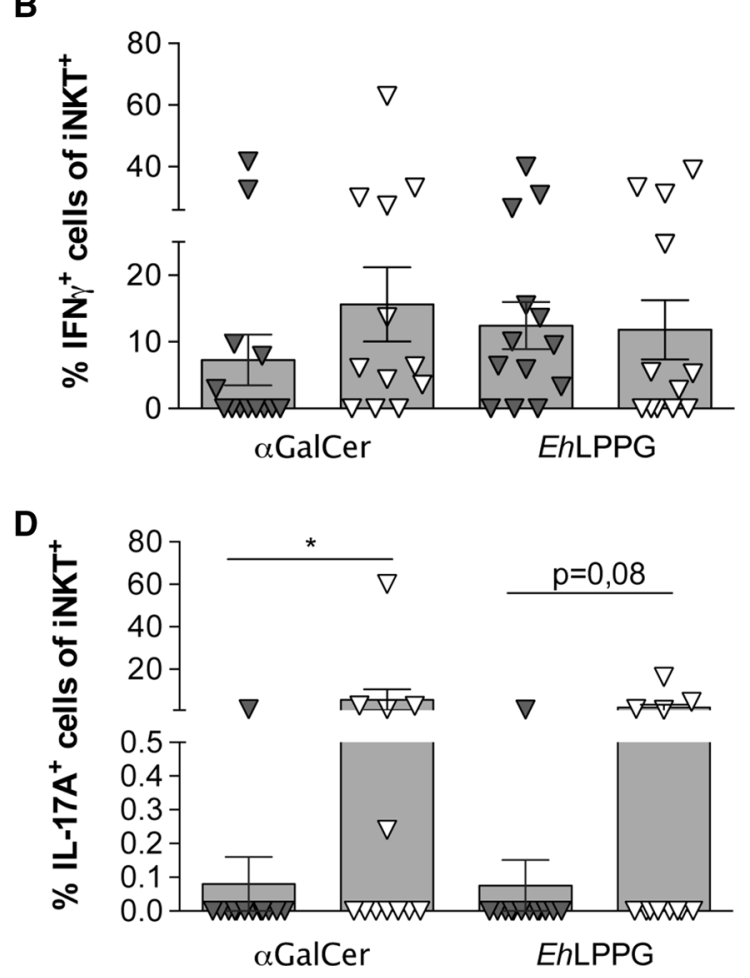

Fig. 2 Comparison of intracellular cytokine production of peripheral NKT cells from men and women following stimulation with $\alpha \mathrm{GalCer}$ and EhLPPG. a Representative gating strategy for the analysis of intracellular cytokine production in peripheral blood NKT cell from men $(n=13)$ and women $(n=12)$. PBMCs were stimulated with

IL-17A production was observed primarily following $\alpha$ GalCer stimulation of $\mathrm{CD}^{+}$and DN NKT cells, and little IL-17A was produced following stimulation with EhLPPG of DN NKT cells. The proportion of $\mathrm{CD}^{+}{ }^{+}$NKT cells was significantly higher in women than in men $(p=0.03$; Fig. 3d).

$\mathrm{CD} 4^{+}$NKT cells were the main cell producers of IL-4 following $\alpha$ GalCer and EhLPPG stimulation, and these cells were more abundant in women following $\alpha \mathrm{GalCer}$ stimulation (women: $17.9 \%$; men: $9.5 \%$; Fig. 3e). EhLPPG induced a higher percentage of $\mathrm{CD} 4^{+} \mathrm{IL}-4^{+} \mathrm{NKT}$
Glycolipid
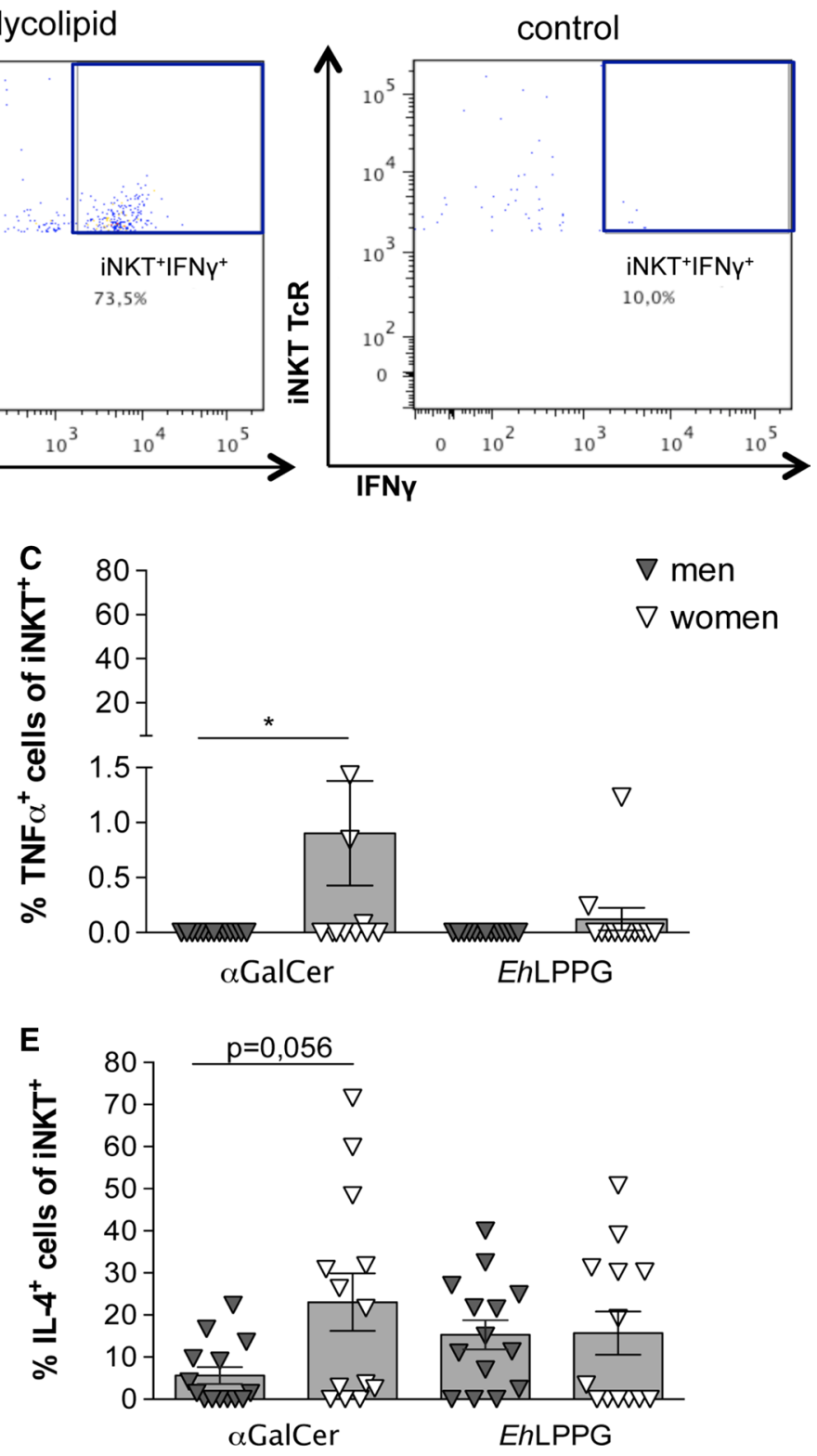

$\alpha \operatorname{GalCer}(1 \mu \mathrm{g} / \mathrm{ml})$ or EhLPPG $(10 \mu \mathrm{g} / \mathrm{ml})$ for $15 \mathrm{~h}$. Percentage of NKT cells positive for intracellular $\mathbf{b}$ IFN $\gamma, \mathbf{c}$ TNF $\alpha, \mathbf{d}$ IL-17A and $\mathbf{e}$ IL-4 production are shown (bars represent Means \pm SEM; statistics: Mann-Whitney $U$ test; $* p<0.05$ )

cells in men (men: $22.9 \%$; women: $14.5 \%$ ). Women had a significantly higher percentage of DN IL- ${ }^{+}$NKT cells $(8.1 \% ; * p=0.03)$ than men, whereas EhLPPG stimulation induced no sex-specific difference in the percentage of DN IL-4 ${ }^{+}$NKT cells.

In summary, these data revealed significant sex-specific differences in IL-17A and IL-4 production in $\mathrm{CD}^{+}$and DN NKT cells, respectively. The $\mathrm{CD}^{+}$and DN NKT subpopulations were the main cytokine producers in women and men. 

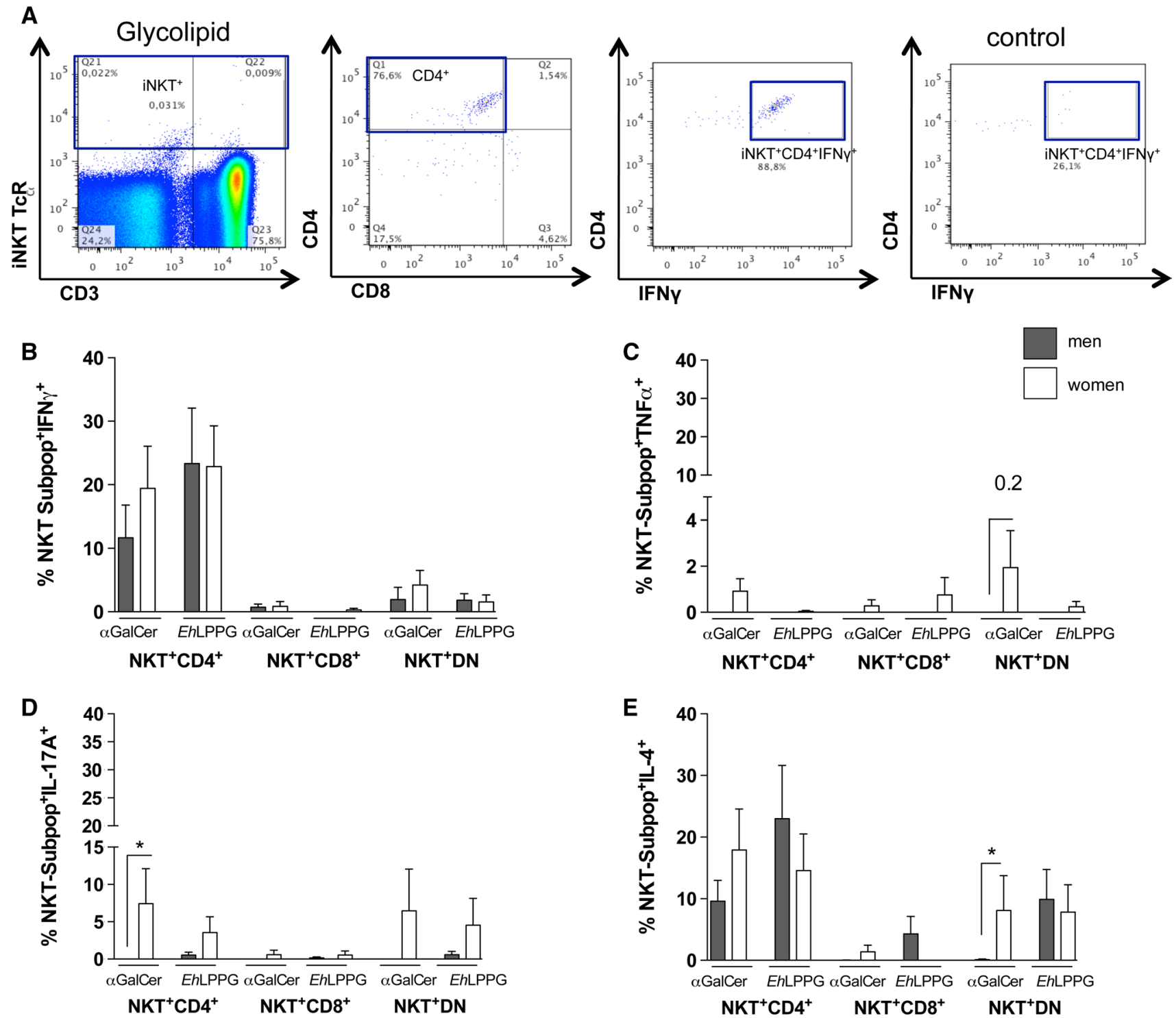

Fig. 3 Intracellular cytokine production in peripheral NKT cell subpopulations from men and women following stimulation with $\alpha$ GalCer and EhLPPG. a Representative gating strategy for the analysis of intracellular cytokine production in peripheral blood NKT cell subpopulations from men $(n=13)$ and women $(n=12)$.

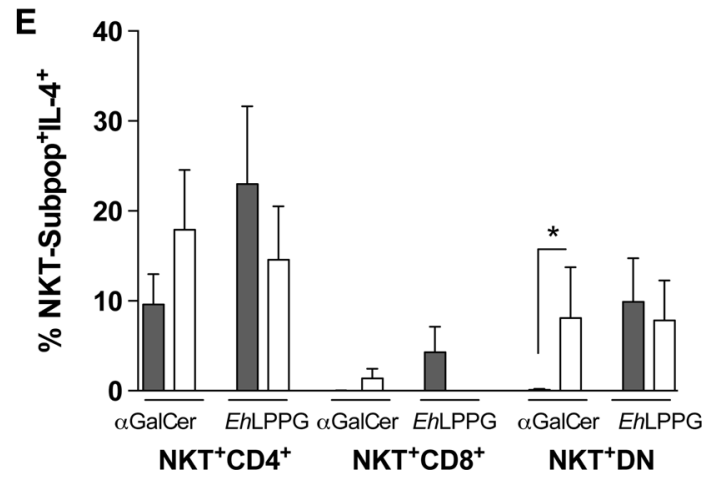

PBMCs were stimulated with $\alpha$ GalCer $(1 \mu \mathrm{g} / \mathrm{ml})$ or EhLPPG (10 $\mu \mathrm{g} /$ $\mathrm{ml}$ ) for $15 \mathrm{~h}$. Percentage of NKT cell subpopulations positive for $\mathbf{b}$ IFN $\gamma, \mathbf{c}$ TNF $\alpha, \mathbf{d}$ IL-17A and e IL-4 NKT are shown (bars represent Means \pm SEM; statistics: Mann-Whitney $U$ test; $\left.{ }^{*} p<0.05\right)$

\section{Sex-specific IFN $\gamma$ production by bystander cells following $\alpha$ GalCer stimulation and addition of autologous APCs}

To investigate sex-specific differences in IFN $\gamma$ production by PBMCs following NKT cell activation, we stimulated PBMCs (Fig. 4a, b) with $\alpha$ GalCer and EhLPPG either alone or in the presence of autologous APCs (Fig. 4c, d). Several donors did not respond to stimulation with $\alpha \mathrm{GalCer}$ and $E h$ LPPG by producing IFN $\gamma$ above the level of the corresponding medium control. Nonetheless, even including

the non-responding donors, we observed slightly higher IFN $\gamma$ production by PBMCs in women, irrespective of the presence or absence of APCs (Fig. 4a, c). When the non-responders were excluded, this difference became more pronounced (Fig. 4b) and the sex-specific difference became statistically significant following stimulation with $\alpha$ GalCer in the presence of APCs $(p<0.05$, Fig. $4 d)$. As described previously [1], EhLPPG must be processed by APCs to exert optimal NKT cell-specific activity. This is reflected in the observation that more subjects responded following the addition of independently generated 

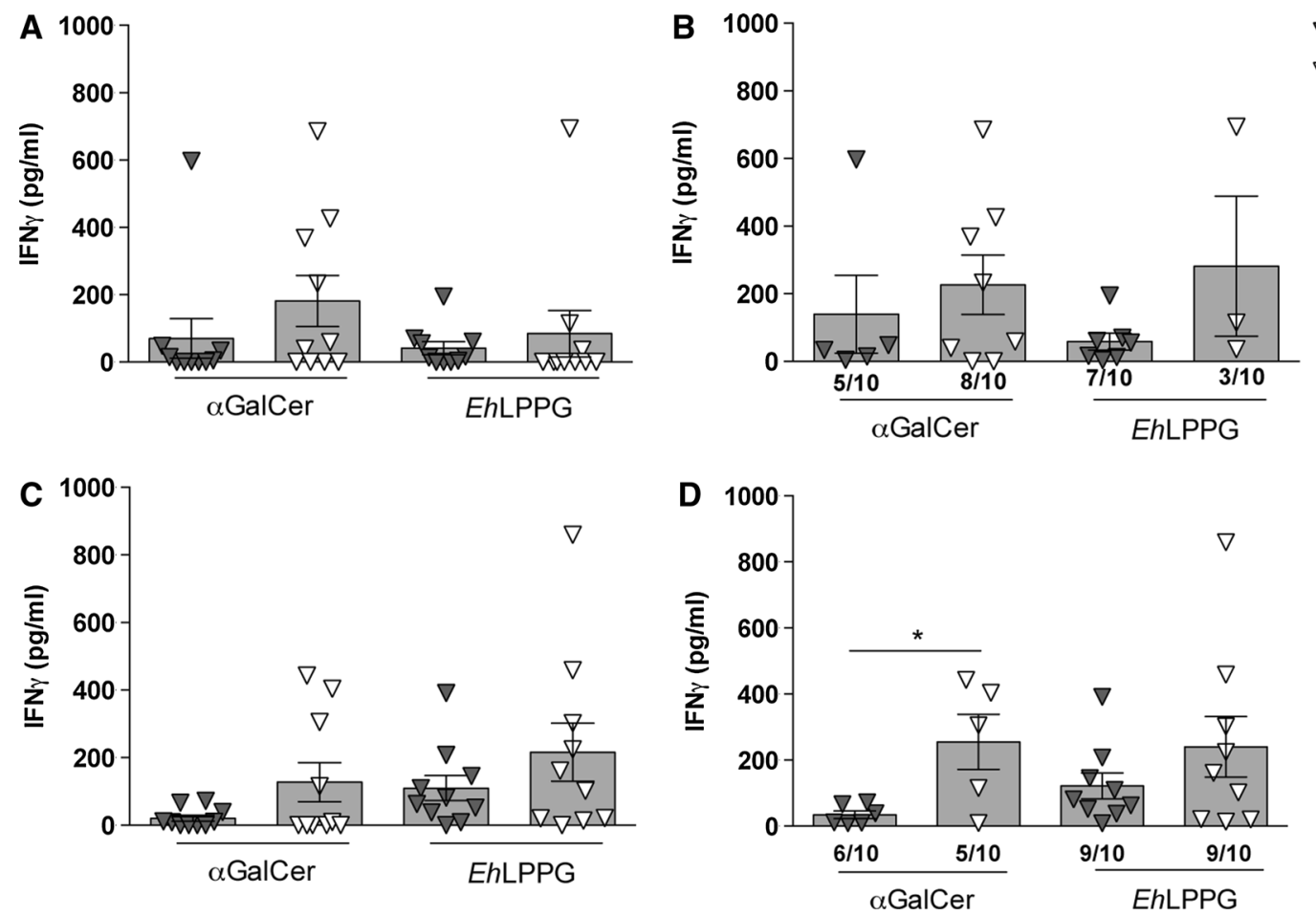

Fig. 4 Influence of autologous APCs on IFN $\gamma$ production by human PBMCs. IFN $\gamma$ production by a PBMCs from male $(n=10)$ and female $(n=10)$ blood donors stimulated with $\alpha$ GalCer $(1 \mu \mathrm{g} / \mathrm{ml})$ or EhLPPG $(20 \mu \mathrm{g} / \mathrm{ml})$ for $48 \mathrm{~h}$. b IFN $\gamma$ production in the same donors excluding samples that did not respond to the indicated stimuli (male, $n=5-7$; female, $n=3-8$ ). IFN $\gamma$ production by c PBMCs from male $(n=10)$ and female $(n=10)$ blood donors co-cultured $48 \mathrm{~h}$ with

homologous APCs (Fig. 4b: men: 7/10 and women: 3/10; Fig. 4d: men: 9/10 and women: 9/10; men PBMC vs. men PBMC with APCs; women PBMC vs. women PBMC with APC). In contrast, we observed no difference between responding and non-responding individuals when $\alpha \mathrm{GalCer}$ was used as the stimulus. Thus, PBMCs contribute to sexspecific IFN $\gamma$ production, and APCs increase the stimulatory activity of $E h$ LPPG.

\section{Expression of multiple cytokines is induced in PBMCs following $\alpha$ GalCer and EhLPPG stimulation}

To extend the analysis of the cytokine repertoire induced by $\alpha \mathrm{GalCer}$ and $E h \mathrm{LPPG}$, we performed a Cytometric Bead Assay (LEGENDplex ${ }^{\mathrm{TM}}$ ) using the supernatants of PBMCs stimulated with different amounts of $\alpha \mathrm{GalCer}$ and EhLPPG from one female donor. Supernatant from unstimulated PBMCs and PBMCs stimulated with antiCD28 were used as controls (Fig. 5a-1). Depending on the concentration of the stimulus agent, most of the 12 cytokines were detectable at significant levels following stimulation with either $\alpha \mathrm{GalCer}$ or EhLPPG. Following stimulation with $0.1 \mu \mathrm{g}-1.0 \mu \mathrm{g} / \mathrm{ml} \alpha \mathrm{GalCer}$, levels of autologous, in vitro generated APCs pulsed with $\alpha$ GalCer $(1 \mu \mathrm{g} / \mathrm{ml})$ or EhLPPG $(20 \mu \mathrm{g} / \mathrm{ml})$. d IFN $\gamma$ production of the same blood donors excluding samples that did not respond to the stimulation by prepulsed APCs (male, $n=6-9$; female, $n=5-9$ ). Cytokine production was measured by ELISA (means \pm SEM; men, $n=10$; women, $n=10$; statistics: unpaired Student's $t$ test; ${ }^{*} p<0.05$ )

TNF, IL-2, IL-17A, IL-17F, IL-6, IL-4, IL-10 and IL-22 were significantly elevated $(p<0.05-0.01)$; IFN $\gamma$, IL-9 and IL-21 levels were elevated, but not significantly; and IL-5 was not detectable at all. Higher concentrations of $\alpha$ GalCer decreased cytokine production. Following stimulation with $0.1 \mu \mathrm{g} / \mathrm{ml}$ EhLPPG, levels of TNF, IL-2, IL17A, IL-17F, IL-6, IL-4, IL-9 and IL-21 were significantly elevated $(p<0.05-0.01)$. IFN $\gamma$ and IL-21 levels were elevated, and IL-5 was not detectable. Increased concentrations of EhLPPG did not lead to an increase in cytokine levels.

In summary, stimulation with $\alpha \mathrm{GalCer}$ and $E h \mathrm{LPPG}$ resulted in the expression of a variety of Th1- and Th2 cytokines in a reverse dose-dependent manner.

\section{The ratio of NKT cell subpopulations in enriched NKT cells is sex specific and stimulus dependent}

Continuous stimulation of the invariant TCR with $\alpha$ GalCer can lead to an enrichment of NKT cells [26]. Therefore, we investigated whether continuous stimulation with $\alpha$ GalCer and EhLPPG over 16 days would increase the total NKT cell number and influence the ratio of NKT cell 


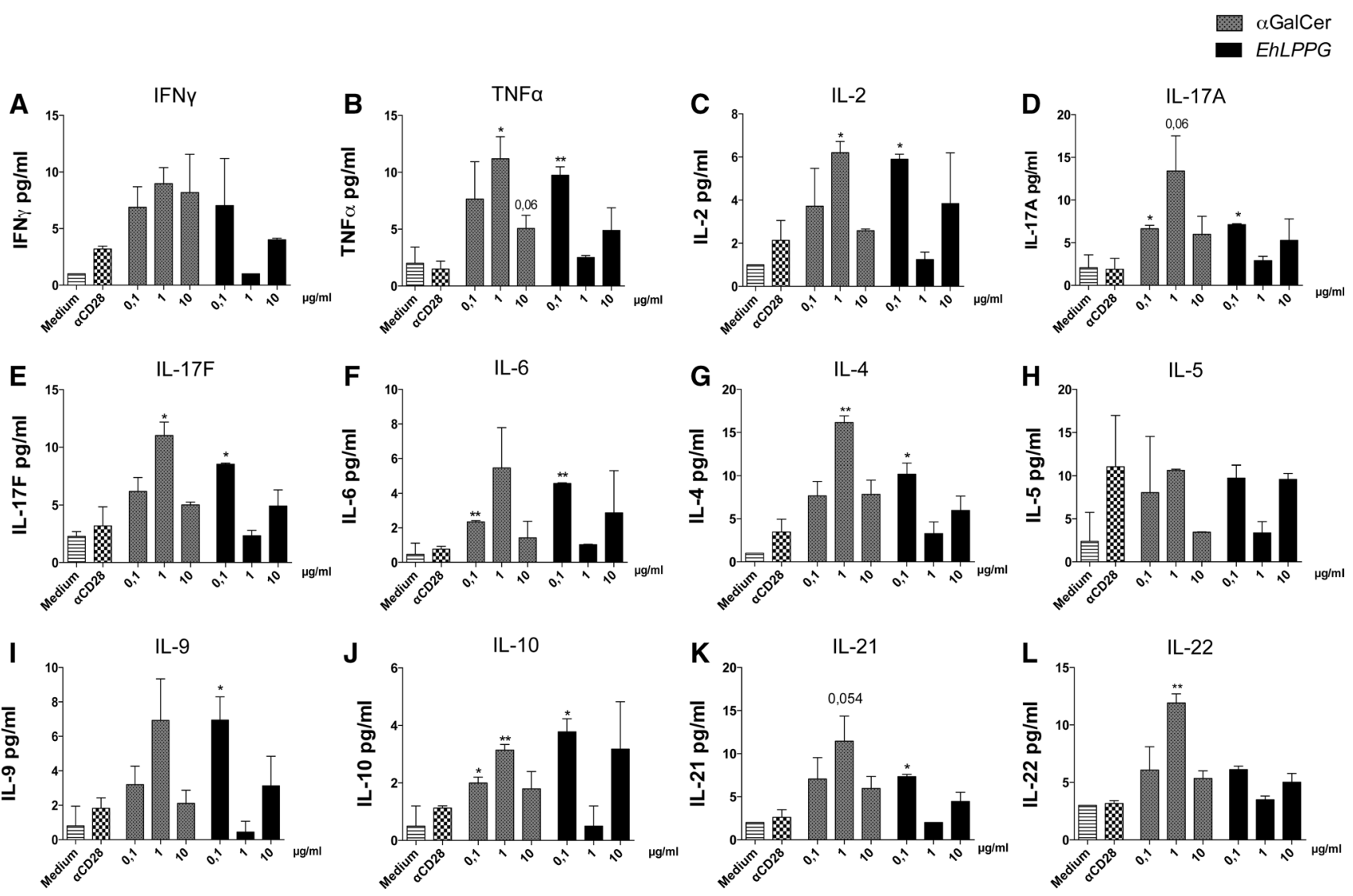

Fig. 5 Spectrum of cytokine production by PBMCs stimulated with $\alpha$ GalCer and EhLPPG. Cytokine profile in the supernatant of PBMCs from a female blood donor stimulated for $15 \mathrm{~h}$ with concentrations of $0.1,1.0$ and $10 \mu \mathrm{g} / \mathrm{ml} \alpha$ GalCer or EhLPPG. LEGENDplex ${ }^{\mathrm{TM}}$ Cyto-

subpopulations in a sex-specific manner (Fig. 6). We stimulated PBMCs from 10 men and 10 women for 16 days with $100 \mathrm{ng} / \mathrm{ml} \alpha \mathrm{GalCer}$ and $400 \mathrm{ng} / \mathrm{ml}$ EhLPPG. Autologous APCs were added on day 9. Interestingly, EhLPPG stimulation did not result in an increase of the total NKT cell number, whereas $\alpha \mathrm{GalCer}$ treatment led to increases on day 8 $(0.36 \%$ in men and $0.35 \%$ in women; $p<0.05)$ and day 16 (1.4\% in men $(p<0.015)$ and $1.0 \%$ in women) (Fig. 6a). Analysis of the NKT cell subpopulations that were enriched over time in the presence of $\alpha$ GalCer revealed similar proportions of $\mathrm{CD}^{+}, \mathrm{CD}^{+}$and DN NKT cells in men and women from day 0 up to day 8 (Fig. 6b, c). On day 16, more $\mathrm{CD} 4^{+}$NKT cells were present in women $(p<0.015)$ than in men, whereas $\mathrm{CD}^{+}$NKT cells $(p<0.043)$ and DN NKT cells were more abundant in men (Fig. 6c). By contrast, over time EhLPPG treatment caused a significant shift toward higher DN NKT cells in women compared to men (day $8, p<0.015$; day 16, $p<0.006$ ), Fig. 6d). This sex-specific shift did not occur when PBMCs were cultured without an NKT cell-stimulating agent (Fig. 6e); under these conditions, we observed a tendency toward a metric Bead Assay (BioLegend) was used to determine the concentrations of a IFN $\gamma$, b TNF $\alpha$, c IL-2, d IL-17A, e IL-17F, f IL-6, g IL-4, h IL-5, i IL-9, j IL-10, k IL-21 and $\mathbf{l}$ IL-22 (means \pm SEM; $n=1$; statistics: unpaired Student's $t$ test; $\left.{ }^{*} p<0.05 ; * * p<0.01\right)$

sex-independent increase in the proportion of $\mathrm{CD}^{+} \mathrm{NKT}$ cells.

In summary, we found that $\alpha$ GalCer, but not EhLPPG, increased NKT cell numbers during long-term culture of PBMCs and both stimuli induced a sex-specific shift in the relative proportions of the NKT cell subpopulations.

\section{Discussion}

Immune responses differ between the sexes, and differences in the frequency and activation of immune cells could contribute to the observed sex-specific differences in infectious and autoimmune diseases. NKT cells are important immune modulators involved in early control of an infection $[14,27]$. As shown recently, the cytokine profile of these cells is modulated by sex hormones; specifically, estrogens increase and testosterone decrease the secretion of the proinflammatory cytokine IFN $\gamma[24,25]$. In this study, we characterized the sex-specific differences in NKT cell frequency and cytokine production in response to the 

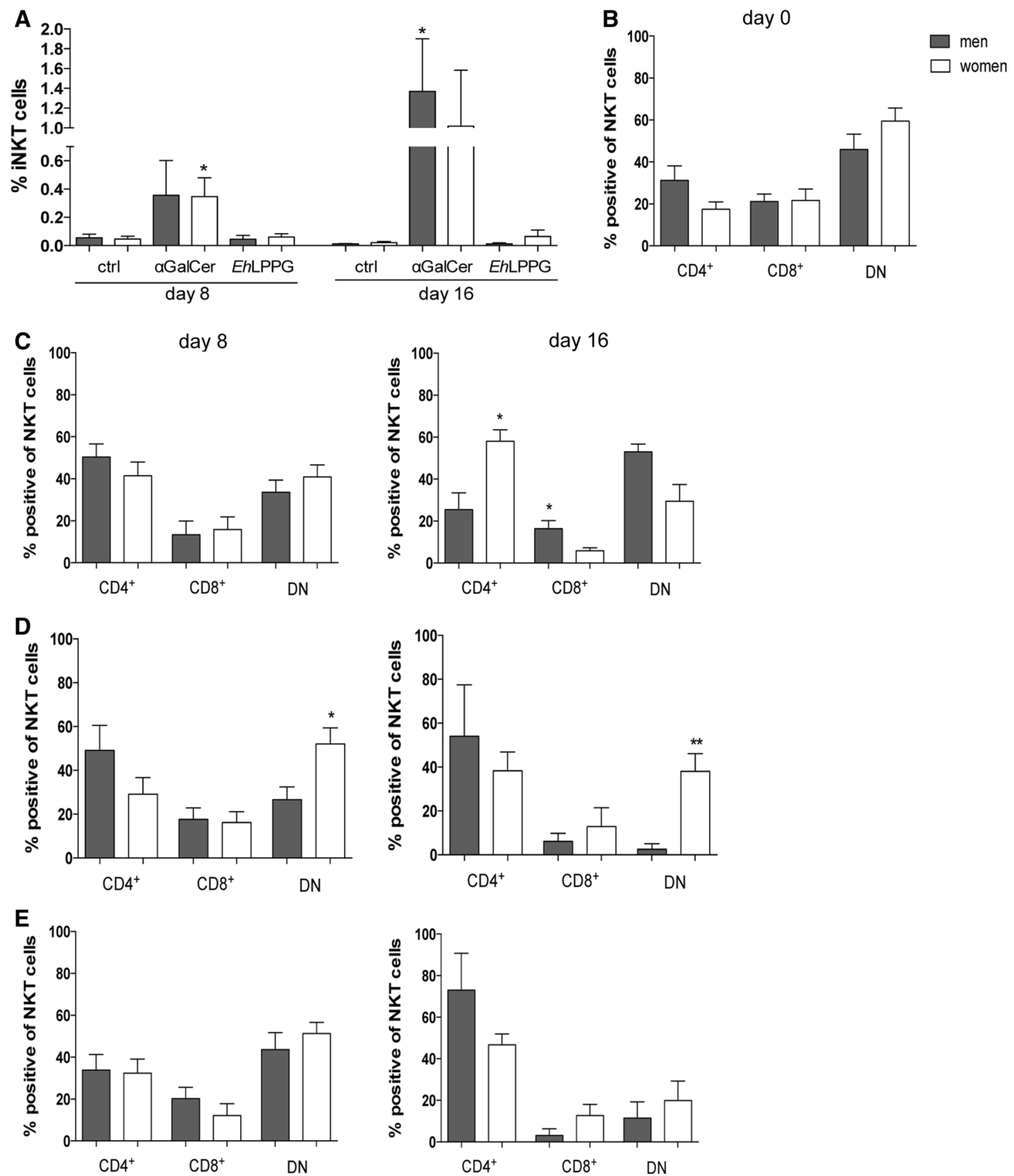

Fig. 6 The ratio of NKT cell subpopulations in enriched NKT cells is sex specific and dependent on stimulant. a Frequency of NKT cells on day 8 and day 16 after enrichment with 20U/ml rh-IL-2, $100 \mathrm{ng} /$ $\mathrm{ml} \alpha \mathrm{GalCer}$ and $400 \mathrm{ng} / \mathrm{ml}$ EhLPPG, respectively. b NKT cell sub-

strong NKT cell activator $\alpha$ GalCer and the moderate NKT cell activator EhLPPG.

Several studies report that the frequency of NKT cells is higher in women than in men [11-13]. We also observed higher NKT cell numbers in women, although the differences were not statistically significant. By contrast, other studies observed no correlation between sex and NKT cell populations in men and women on days 0,8 and 16 in the presence of $\mathbf{c} \alpha \mathrm{GalCer}, \mathbf{d} E h \mathrm{LPPG}$ or e rh-IL-2 alone (control) (means \pm SEM; men, $n=10$; women, $n=10$; statistics: unpaired Student's $t$ test; $* p<0.05$ )

frequency [19, 28]. Various studies report different ratios of NKT cell subpopulations in each sex. We observed slightly higher percentages of $\mathrm{CD}^{+}$and $\mathrm{CD}^{+}{ }^{+} \mathrm{NKT}$ cells in men and higher percentages of DN NKT cells in women. Two other studies also observed higher $\mathrm{CD}^{+}{ }^{+} \mathrm{NKT}$ cell numbers in men [11, 13], whereas another study observed the opposite distribution in this subpopulation and more 
$\mathrm{CD}^{+}$and DN NKT cells in men [19]. Consistent with our results, Kee et al. [13] also observed a higher frequency of DN NKT cells in the peripheral blood of women. These differences in the observed frequencies of NKT cells and their subpopulations may be due to the quantity or age of the subjects in each study. Consistent with this idea, several studies showed that NKT cell frequency significantly decreases with age [28-31]. Moreover, the sex-specific difference in the abundance of NKT cells may have an impact on diseases with sexual dimorphism. Human DN NKT cells mainly produce Th1 cytokines [32]. Therefore, the elevated percentage of DN NKT cells in women suggests that production of protective IFN $\gamma$ during infection will be higher in women than in men. Parasite-induced amebic liver abscess (ALA) has a strong sex bias toward men, and a mouse model of the disease exhibits a similar preference toward males; however, the resistance of female mice is abolished in mice lacking NKT cells and IFN $\gamma$ [1].

Sex-specific differences in cytokine secretion were documented for several immune cell populations. Phytohemagglutinin-stimulated lymphocytes from male blood donors produced higher levels of IFN $\gamma$ and IL-2 and lower levels of IL-4 and IL-10 than those from females [33]. Additionally, following LPS stimulation monocytes from men produce more TNF $\alpha$, IL- $1 \beta$ and IL-12 than those from women [2]. In the mouse model of ALA, NKT cells from female mice produce more IFN $\gamma$ than NKT cells from male mice [25] and female mice have higher serum IFN $\gamma$ levels following $\alpha \mathrm{GalCer}$ treatment [24]. In part due to the extremely low number of circulating NKT cells in men $(0.001-0.1 \%)$, little is known about sex-specific differences in the cytokine production by human NKT cells. In this study, however, we were able to analyze intracellular cytokine production by peripheral NKT cells by flow cytometry. We found that stimulation with the strong NKT cell activator $\alpha \mathrm{GalCer}$ resulted in significantly more $\mathrm{TNF} \alpha$ and IL-17A-positive NKT cells and a trend toward more IFN $\gamma$ and IL-4-positive NKT cells in female blood donors. By contrast, EhLPPG stimulation induced no sex difference in the production of IFN $\gamma, \mathrm{TNF} \alpha$ or IL- 4 by NKT cells and a non-statistically significant increase in the percentage of IL-17A-positive NKT cells in women. Among the three NKT cell subpopulations, $\mathrm{CD}^{+}{ }^{+}$and DN NKT cells were the major cytokine producers. In particular, $\mathrm{CD}^{+}{ }^{+}$and $\mathrm{DN}$ NKT cells from female blood donors produced significantly more IL-17A after $\alpha$ GalCer stimulation. In addition, more IL- $4^{+}$DN NKT cells were present in samples from female blood donors. EhLPPG induced no significant sex difference in the cytokine production by NKT cells, although a tendency toward sex-specific differences could be observed for $\mathrm{IL}-17 \mathrm{~A}^{+} \mathrm{CD} 4^{+}$, IL- $17 \mathrm{~A}^{+} \mathrm{DN}$ and $\mathrm{IL}-4^{+} \mathrm{CD} 4^{+} \mathrm{NKT}$ cells. By contrast, mitogen stimulation of sorted human NKTs resulted in higher proportions of IFN $\gamma$-, TNF $\alpha$ - and
MIP-1- $\alpha$-producing NKT cells in men than in women, but no difference in IL-4 production by NKT cells [19].

In another study using in vitro expanded human NKT cells, $\alpha$ GalCer stimulation induced Th1 and Th2 cytokines in all three NKT subpopulations, but cytokine production was higher in $\mathrm{CD}^{+}$NKT cells than in $\mathrm{CD}^{+}$and DN NKT cells [20]. Analysis of cytokine production by PBMCs following specific NKT cell activation by $\alpha$ GalCer or EhLPPG revealed that non-NKT cells also contribute to cytokine production, putatively via indirect activation, which might reflect the immunoregulatory properties of NKT cells. In this study, we observed induction of a variety of cytokines, including the Th1 cytokines IFN $\gamma$, TNF, IL-17 A/F and IL-2 and the Th2 cytokines IL-4 and IL-10, as well as a strong induction of the pluripotent cytokine IL-6.

This observation might indicate that NKT cells express a sex-specific cytokine repertoire that differs depending on the used stimulant. A specific ligand like $\alpha$ GalCer may induce a gene expression pattern that involves sex hormone receptors, leading to a sex-dependent cytokine production. By contrast, a less specific mitogenic ligand like phytohaemagglutinin may induce more general regulation of immunity-related gene expression and might reflect the chromosomal repertoire of possible cytokine production.

The nature of the stimulus may also be important for the sex specificity of APCs such as plasmacytoid DCs (pDCs), which influence the subsequent cytokine production in responding immune cells. For example, pDCs from women produce higher levels of IFN $\alpha$ following ligation of the TLR7-agonist imiquimod, a heterocyclic amine, than pDCs from men [34]. Moreover, immune cells from female mice and rats express higher levels of pathogen recognition receptors, such as TLR2, 3 and 4, and mount a more efficient immune response against specific pathogens than those from male rats [35]. In our assays, we also observed a sex-specific influence of APCs on immune activation. Although sex-specific differences in cytokine production were also observed in the absence of separately generated autologous APCs, addition of these cells revealed more pronounced differences between the sexes.

The stimulus could also modulate the ratio of NKT cell subpopulations in a sex-dependent manner. Along these lines, we found that $\alpha \mathrm{GalCer}$ induced strong NKT cell enrichment and favored the development of higher proportions of $\mathrm{CD}^{+}{ }^{+} \mathrm{NKT}$ cells in PBMC cultures from female blood donors and higher proportions of $\mathrm{CD}^{+}$and $\mathrm{DN}$ NKT cells in the cultures from male blood donors. EhLPPG induced no enrichment of NKT cells, but still influenced the ratio of the NKT cell subpopulation over the course of long-term culture. Under these conditions, we observed a shift toward the $\mathrm{CD} 4^{+}$NKT cell subpopulation in men and $\mathrm{CD}^{+}{ }^{+}$and DN NKT cell subpopulation in women. 
Therefore, because EhLPPG facilitates NKT cell activation through engagement of TLR2, TLR4 and TLR6 [1], we hypothesize that $E h L P P G$ provides a survival signal that is sufficient to alter the ratio of the NKT cell subpopulations.

In conclusion, we showed that women tend to have higher NKT cell frequencies than men and that their NKT cells produce significantly more TNF $\alpha$ and IL-17A following $\alpha \mathrm{GalCer}$ stimulation. Moreover, a strong stimulus like $\alpha \mathrm{GalCer}$ is more likely to induce distinct and significant sex-specific differences in the cytokine profile of human NKT cells than a more moderate or weaker stimulus such EhLPPG. Some stimuli may induce sex differences and a sex-specific outcome of a disease, whereas others may induce similar immune responses in both men and women. Sex hormones and X-chromosome-linked immune regulatory genes are thought to be major players in sex-specific immune responses, but the precise details of their regulatory biology and interactions remain unclear. Although some immune cell subsets exhibit sex-specific differences in frequency, the quality of the mounted immune response is likely to be far more important for sexual dimorphism in disease than the quantities of immune cells involved.

Funding This work was supported by grants of the Collaborative Research Center 841, Bonn, Germany; the Bernhard Nocht Institute for Tropical Medicine, the Werner-Otto Stiftung and the "Vereinigung der Freunde des Tropeninstituts Hamburg, E.V.," Hamburg, Germany.

\section{Compliance with ethical standards}

Conflict of interest The authors do not have a commercial or other association that might pose a conflict of interest (e.g., pharmaceutical stock ownership, consultancy, advisory board membership, relevant patents, or research funding). The funders had no role in study design, data collection and analysis, decision to publish, or preparation of the manuscript. No information within the manuscript beyond the cited literature has been published by another journal.

Open Access This article is distributed under the terms of the Creative Commons Attribution 4.0 International License (http://creativecommons.org/licenses/by/4.0/), which permits unrestricted use, distribution, and reproduction in any medium, provided you give appropriate credit to the original author(s) and the source, provide a link to the Creative Commons license, and indicate if changes were made.

\section{References}

1. Lotter H, Gonzalez-Roldan N, Lindner B, Winau F, Isibasi A, Moreno-Lafont M, Ulmer AJ, Holst O, Tannich E, Jacobs T (2009) Natural killer T cells activated by a lipopeptidophosphoglycan from Entamoeba histolytica are critically important to control amebic liver abscess. PLoS Pathog 5(5):e1000434

2. Bouman A, Schipper M, Heineman MJ, Faas MM (2004) Gender difference in the non-specific and specific immune response in humans. Am J Reprod Immunol 52(1):19-26. doi:10.1111/j.1600-0897.2004.00177.x
3. Klein SL, Roberts CWE (2015) Sex and gender differences in infection and treatments for infectious diseases. Springer, New York

4. Neyrolles O, Quintana-Murci L (2009) Sexual inequality in tuberculosis. PLoS Med 6(12):e1000199

5. Klein SL (2004) Hormonal and immunological mechanisms mediating sex differences in parasite infection. Parasite Immunol 26(6-7):247-264

6. Blessmann J, Van Linh P, Nu PA, Thi HD, Muller-Myhsok B, Buss H, Tannich E (2002) Epidemiology of amebiasis in a region of high incidence of amebic liver abscess in central Vietnam. Am J Trop Med Hyg 66(5):578-583

7. Bernin H, Lotter H (2014) Sex bias in the outcome of human tropical infectious diseases: influence of steroid hormones. J Infect Dis 209(Suppl 3):S107-S113. doi:10.1093/infdis/jit610

8. Bernin H, Marggraff C, Jacobs T, Brattig N, Le VA, Blessmann J, Lotter H (2014) Immune markers characteristic for asymptomatically infected and diseased Entamoeba histolytica individuals and their relation to sex. BMC Infect Dis 14:621. doi:10.1186/ s12879-014-0621-1

9. Giefing-Kroll C, Berger P, Lepperdinger G, Grubeck-Loebenstein B (2015) How sex and age affect immune responses, susceptibility to infections, and response to vaccination. Aging Cell 14(3):309-321. doi:10.1111/acel.12326

10. Bouman A, Heineman MJ, Faas MM (2005) Sex hormones and the immune response in humans. Hum Reprod Update 11(4):411-423

11. Sandberg JK, Bhardwaj N, Nixon DF (2003) Dominant effector memory characteristics, capacity for dynamic adaptive expansion, and sex bias in the innate V $\alpha 24$ NKT cell compartment. Eur J Immunol 33(3):588-596. doi:10.1002/eji.200323707

12. Montoya CJ, Pollard D, Martinson J, Kumari K, Wasserfall C, Mulder CB, Rugeles MT, Atkinson MA, Landay AL, Wilson SB (2007) Characterization of human invariant natural killer T subsets in health and disease using a novel invariant natural killer $\mathrm{T}$ cell-clonotypic monoclonal antibody, 6B11. Immunology 122(1):1-14. doi:10.1111/j.1365-2567.2007.02647.x

13. Kee SJ, Park YW, Cho YN, Jin HM, Kim MJ, Lee SJ, Kim TJ, Lee SS, Kwon YS, Jang HC, Kim N, Shin MG, Shin JH, Suh SP, Ryang DW (2012) Age- and gender-related differences in circulating natural killer $\mathrm{T}$ cells and their subset levels in healthy Korean adults. Hum Immunol 73(10):1011-1016. doi:10.1016/j. humimm.2012.07.335

14. Godfrey DI, Stankovic S, Baxter AG (2010) Raising the NKT cell family. Nat Immunol 11(3):197-206. doi:10.1038/ni.1841

15. Tupin E, Kinjo Y, Kronenberg M (2007) The unique role of natural killer $\mathrm{T}$ cells in the response to microorganisms. Nat Rev Microbiol 5(6):405-417

16. Van Kaer L, Parekh VV, Wu L (2011) Invariant natural killer T cells: bridging innate and adaptive immunity. Cell Tissue Res 343(1):43-55. doi:10.1007/s00441-010-1023-3

17. Godfrey DI, Kronenberg M (2004) Going both ways: immune regulation via CD1d-dependent NKT cells. J Clin Investig 114(10):1379-1388. doi:10.1172/JCI23594

18. Bendelac A, Savage PB, Teyton L (2007) The biology of NKT cells. Annu Rev Immunol 25:297-336. doi:10.1146/annurev. immunol.25.022106.141711

19. Snyder-Cappione JE, Tincati C, Eccles-James IG, Cappione AJ, Ndhlovu LC, Koth LL, Nixon DF (2010) A comprehensive ex vivo functional analysis of human NKT cells reveals production of MIP1- $\alpha$ and MIP1- $\beta$, a lack of IL-17, and a Th1bias in males. PLoS One 5(11):e15412. doi:10.1371/journal. pone. 0015412

20. O'Reilly V, Zeng SG, Bricard G, Atzberger A, Hogan AE, Jackson J, Feighery C, Porcelli SA, Doherty DG (2011) Distinct and overlapping effector functions of expanded human $\mathrm{CD}^{+}$, 
CD8 $\alpha^{+}$and CD4-CD8 $\alpha$-invariant natural killer T cells. PLoS One 6(12):e28648. doi:10.1371/journal.pone.0028648

21. Godfrey DI, MacDonald HR, Kronenberg M, Smyth MJ, Van Kaer L (2004) NKT cells: what's in a name? Nat Rev Immunol 4(3):231-237

22. Veerapen N, Reddington F, Salio M, Cerundolo V, Besra GS (2011) Synthesis of truncated analogues of the iNKT cell agonist, $\alpha$-galactosyl ceramide (KRN7000), and their biological evaluation. Bioorg Med Chem 19(1):221-228. doi:10.1016/j. bmc.2010.11.032

23. Mattner J, Debord KL, Ismail N, Goff RD, Cantu C 3rd, Zhou D, Saint-Mezard P, Wang V, Gao Y, Yin N, Hoebe K, Schneewind O, Walker D, Beutler B, Teyton L, Savage PB, Bendelac A (2005) Exogenous and endogenous glycolipid antigens activate NKT cells during microbial infections. Nature 434(7032):525-529

24. Gourdy P, Araujo LM, Zhu R, Garmy-Susini B, Diem S, Laurell H, Leite-de-Moraes M, Dy M, Arnal JF, Bayard F, Herbelin A (2005) Relevance of sexual dimorphism to regulatory T cells: estradiol promotes IFN- $\gamma$ production by invariant natural killer $\mathrm{T}$ cells. Blood 105(6):2415-2420

25. Lotter H, Helk E, Bernin H, Jacobs T, Prehn C, Adamski J, Gonzalez-Roldan N, Holst O, Tannich E (2013) Testosterone increases susceptibility to amebic liver abscess in mice and mediates inhibition of IFN $\gamma$ secretion in natural killer T cells. PLoS One 8(2):e55694. doi:10.1371/journal.pone.0055694

26. Watarai H, Nakagawa R, Omori-Miyake M, Dashtsoodol N, Taniguchi M (2008) Methods for detection, isolation and culture of mouse and human invariant NKT cells. Nat Protoc 3(1):70-78. doi:10.1038/nprot.2007.515

27. Van Kaer L, Parekh VV, Wu L (2015) The response of CD1drestricted invariant NKT cells to microbial pathogens and their products. Front Immunol 6:226. doi:10.3389/fimmu.2015.00226

28. Jing Y, Gravenstein S, Chaganty NR, Chen N, Lyerly KH, Joyce S, Deng Y (2007) Aging is associated with a rapid decline in frequency, alterations in subset composition, and enhanced
Th2 response in CD1d-restricted NKT cells from human peripheral blood. Exp Gerontol 42(8):719-732. doi:10.1016/j. exger.2007.01.009

29. DelaRosa O, Tarazona R, Casado JG, Alonso C, Ostos B, Pena J, Solana R (2002) V $\alpha 24^{+}$NKT cells are decreased in elderly humans. Exp Gerontol 37(2-3):213-217

30. Molling JW, Kolgen W, van der Vliet HJ, Boomsma MF, Kruizenga $\mathrm{H}$, Smorenburg $\mathrm{CH}$, Molenkamp BG, Langendijk JA, Leemans CR, von Blomberg BM, Scheper RJ, van den Eertwegh AJ (2005) Peripheral blood IFN- $\gamma$-secreting V $\alpha 24^{+} \mathrm{V} \beta 11^{+}$ NKT cell numbers are decreased in cancer patients independent of tumor type or tumor load. Int J Cancer 116(1):87-93. doi:10.1002/ijc.20998

31. Peralbo E, DelaRosa O, Gayoso I, Pita ML, Tarazona R, Solana $R$ (2006) Decreased frequency and proliferative response of invariant $\mathrm{V} \alpha 24 \mathrm{~V} \beta 11$ natural killer $\mathrm{T}$ (iNKT) cells in healthy elderly. Biogerontology 7(5-6):483-492. doi:10.1007/ s10522-006-9063-5

32. La Cava A, Van Kaer L, Fu Dong S (2006) CD4 ${ }^{+}$CD $25^{+}$Tregs and NKT cells: regulators regulating regulators. Trends Immunol 27(7):322-327. doi:10.1016/j.it.2006.05.003

33. Giron-Gonzalez JA, Moral FJ, Elvira J, Garcia-Gil D, Guerrero F, Gavilan I, Escobar L (2000) Consistent production of a higher TH1:TH2 cytokine ratio by stimulated T cells in men compared with women. Eur J Endocrinol 143(1):31-36

34. Meier A, Chang JJ, Chan ES, Pollard RB, Sidhu HK, Kulkarni S, Wen TF, Lindsay RJ, Orellana L, Mildvan D, Bazner S, Streeck H, Alter G, Lifson JD, Carrington M, Bosch RJ, Robbins GK, Altfeld M (2009) Sex differences in the Toll-like receptor-mediated response of plasmacytoid dendritic cells to HIV-1. Nat Med 15(8):955-959. doi:10.1038/nm.2004

35. Scotland RS, Stables MJ, Madalli S, Watson P, Gilroy DW (2011) Sex differences in resident immune cell phenotype underlie more efficient acute inflammatory responses in female mice. Blood 118(22):5918-5927. doi:10.1182/blood-2011-03-340281 